Srđan Mladenov Jovanović

Nankai University, China

Ajdin Đidić

Ibn Haldun University, Turkey

\title{
DISCURSIVE GOVERNANCE: ERDOĞAN'S POPULIST DISCOURSES AS A MODE OF POWER PRESERVATION
}

\begin{abstract}
Although he used to be praised by the West as a modernizer of Turkey, Erdoğan's mode and discourse of governance have changed drastically over the last decade - he now employs severe counter-democratic measures and exclusionary, populist discourses. This article explores Erdoğan's rule, focusing in particular on the discourses he promotes in order to keep power and attain increasing electoral support. In an analysis based on the theoretical foundations of Critical Discourse Analysis, Erdoğan's reign is characterized by specific, exclusionary discourses, from creating the discursive Other established as the enemy and engaging in conspiracy discourses, to openly chastising and castigating his political opponents, while his popularity continues to increase.
\end{abstract}

Key words

Erdoğan, Turkey, Critical Discourse Analysis, governance, conspiracy 


\section{Power, populism and discourse}

The case of the Turkish AKP and Recep Tayyip Erdoğan in particular can be seen to stand as an illustration of Lord Acton's famed statement: "Power corrupts; absolute power corrupts absolutely". Hailed as a great power of change by conservatives, centrists, liberals, intellectuals and Westerners alike, the Party of Justice and Development (henceforth referred to as AKP, for Adalet ve Kalkınma Partisi) came as a reaction to the oppressive secularist regime which was permeating bureaucracy, state, and military apparatuses following the events of 28 February 1997, otherwise known as the "Post-modern coup", when the Islamist Prime Minister Necmettin Erbakan was forced to resign. In 2002 BBC wrote, "Europe hails AKP victory in Turkey" (Mann \& Rodgers, 2002), while Yesil spoke that "Turkey has been hailed as a regional leader in the Middle East and a successful amalgamation of moderate Islam and democracy" (2014, p. 1); a decade and a half later, the situation has changed drastically. The Post-modern coup events opened a manoeuvring space for the younger cadre of Erbakan's followers known as National Outlook (Millî Görüş), which later became known as AKP. The young protégés of Erbakan (such as Erdoğan, Ahmet Davutoglu and Abdullah Gul), who now had the opportunity to stand on their own feet, uninhibited by the old guard of the National Outlook ideology, and could thus infiltrate the Turkish political stage. Whether one mentions Erbakan's conservatism in social and spiritual life, or Ozal's neoliberalism coupled with globalization, the truth was that the AKP represented it all (Kösebalaban, 2011, p. 146). It was small wonder then that the majority of important groups in Turkey and the West greeted this as a positive change. It took time to notice how much a political party, led by its key personalities, has been able to re-orient itself in order to ride the wave of populism that it itself has created.

When it comes to literature on the topic, populism per se has been extensively studied, especially during the last several decades, when it has become particularly potent, which led to coining phrases such as "populist zeitgeist" (Mudde, 2004), and spawning a vast array of theoretical work struggling to define it (Mudde \& Kaltwasser, 2012; Müller, 2016; Rydgren, 2005; Taggart, 2002; Taguieff, 1995). For the purpose of this work, the authors shall take the middle ground, seeing that "in the current debate, 'populism' is mostly associated with an emotional, simplistic, and manipulative discourse directed at the 'gut feelings' of the people, or with opportunistic policies aimed at 'buying' support" (Krastev, 2007, p. 2). It would be also wise to notice that "populists do not just thrive on conflict and encourage polarization; they also treat their political opponents as 
'enemies of the people' and seek to exclude them altogether" (Müller, 2016, p. 4), thus helping themselves stay in power, which will be shown as the primary modus operandi of the Erdoğan regime. Turkey itself has, consequently, been the focus of many academic works after Erdoğan's coming into power (Arin, 2017; Aytaç \& Çarkoğlu, 2019; Cagaptay, 2019; Jovanović \& Đidić, 2018; Özdamar \& Ceydilek, 2020; Yavuz \& Öztürk, 2019; Yilmaz et al., 2020).

The purpose of the article is to show that Erdoğan's authoritarian turn is closely connected to his wish to preserve his personal power over the Turkish state. Moreover, what follows from this is that Erdoğan deliberately makes questionable domestic policy decisions in order to secure his own position although their implementation might be to the detriment of the Turkish public and state. Indicators of this are varied. How Erdoğan works in his own interest will be demonstrated through examining his discourse during his alliance with Gülen and the Hizmet movement against Kemalists, and then cross-comparing it with his post-2011/2012 stance towards Cemaat, which ultimately lead to the attempted coup of 2016.

The last issue to be examined is how Erdoğan has been dealing with a vacuum left by removal of Gülenists and what that means for him in particular and the state in general - examined with the Critical Discourse Analysis as a starting point, a method which is used increasingly often in political science (Chaney, 2013; Howarth \& Torfing, 2004; Larsen, 2005). The discourses promulgated by the state elite serve a purpose, i.e. keeping power. Discourse itself in such contexts is defined as "the instrument of power and control" (Van Leeuwen, 1993, p. 193). This is why Critical Discourse Analysis "may be defined as fundamentally concerned with analysing opaque as well as transparent structural relationships of dominance, discrimination, power and control as manifested in language" (Wodak, 2001, p. 2) because it primarily focuses on the "analysis of current discourses and the effects of their power" (Jäger, 2001, p. 33). Thus for the purpose of this research discourse will be defined as "an institutionally consolidated concept of speech inasmuch as it determines and consolidates action and thus already exercises power" (Link, 1983, p. 60). In other words, "discourses are not interesting as mere expressions of social practice, but because they serve certain ends, namely to exercise power with all its effects" (Jäger, 2001, p. 34).

\section{Authority and its enemies}

It became clear that Erdoğan had no intention of relinquishing his position of authority. It is rather common in countries which do not have stable institutional 
grounding that leaders who came to power with the majority of votes turn into populist demagogues with the talent for manipulating popular opinion and weakening institutions even further (Özsoy, 2009); here a comparison with Serbia's Aleksandar Vučić or Russia’s Vladimir Putin comes to mind. Empirical evidence indicates that it would not be a mistake to interpret Erdoğan's actions as Machiavellism, dubbed also "Erdoğan's realism", in the realpolitik sense (Đidić, 2017). Hence, Erdoğan became known for making and breaking alliances. Erdoğan's discourse in the relation to Fetullah Gülen, the leader of what is now dubbed by Turkish authorities as a "terrorist organization", is thus rather pertinent. What Erdoğan called a "terrorist organization" is in fact a loose web of entrepreneurial projects, institutions, NGOs, and educational facilities which $\mathrm{BBC}$ has described as one of the "largest Muslim networks in the world" (BBC, 2013). It is a network of organizations following the teachings of Fetullah Gülen, which adapts Islam to globalization and new transnational environment, unifying several traditional and cultural religious interpretations that are opposed to the rise of extremist currents in the Muslim world (Economist, 2013). The discursive construction of the enemy is an iterating instance in the study of political discourse, as "the transformation of an adversary into an enemy is supported by a set of discourses, articulating the identities of all parties involved. These discourses play a crucial role" (Carpentier, 2011, pp. 1-2). In Mouffe's words, "the opponent cannot be perceived as an adversary to contend with, but only as an enemy to be destroyed" (1993, p. 4), or, as Carpentier wrote, "these discourses on the Enemy are based on a series of binary oppositions, such as good/evil, just/ unjust, guilty/innocent, rational/irrational and civilised/uncivilised' (2011, p. 1); Gülen is now "evil” while Erdoğan is "good".

However, Erdoğan's relationship with Gülen was not always one of animosity. United by common interest, they cooperated more often than not. D'Amours (2017) claims that Erdoğan and Gülen were "partners in trying to assume power for decades". Both saw Turkish secular establishment as a threat, and in order to overcome this, it was pragmatic for them to cooperate (Dorsey, 2016). Therefore, Gülen and his organization (aka Hizmet) allied with the AKP, helping them win the elections of 2002, 2007 and 2011. In exchange, Gülen spread his influence over various branches of the Turkish state, most notably the police, judiciary and state bureaucracy (Sharon-Krespin, 2009). The most significant of the elections in this sense was that of 2007, when the AKP further consolidated its position by winning $46.6 \%$ of the votes. One year after the electoral victory, the AKP, allied with Gülenists, initiated legal proceedings in what came to be known as the Ergenekon case (Ergenekon davasi), followed by the Sledgehammer 
operation, with Ergenekon being a name given to a supposed clandestine, ultranationalist organization set on overthrowing the government. Retrospectively, it is clear how these proceedings provided an opportunity for the established regime to further remove its obstacles and political adversaries, thus helping Erdoğan curtail the power of the Turkish military, which had been a continuous threat to the democratically elected regimes since the early years of the Republic, and allowing Gülen to tighten his grasp on the state apparatus. One notable event was the arrest (as a part of the Ergenekon investigation) of the journalist Ahmet Sik, who was working on the book entitled The Imam's Army (Imamin Ordusu), which presented findings on Gülen's influences in Turkey's security and intelligence spheres (Zubaida, 2017). Soon, beside secular military personnel and alleged terrorist organization members, a large number of other people were arrested, including critics of Gülen, such as the aforementioned left-leaning journalists (Oktay, 2016). These events set a precedent where the AKP in its later years (recently in particular) continued to stifle and abuse the rights and liberties of the media, an issue which has attracted a lot of researchers (Akser \& Baybars-Hawks, 2012; Christensen, 2010; Jenkins, 2012; Yllmaz, 2016). The entire Ergenekon scandal turned out to be, in essence, a charade orchestrated primarily by Gülen with the AKP's tacit support in order to protect their realpolitik principles. The evidence found was later proven to be forged, and by 2014, in the wake of his falling out with Gülen even Erdoğan himself was drawing attention to this fact (Arango, 2014). That Erdoğan's relation with Gülen was mostly opportunistic from the start is not overly difficult to notice. As already mentioned, during the first decade of their rule Erdoğan and the AKP could be considered as liberal conservatives, with a dose of respect for Western values and hence a pro-Western foreign policy outlook, particularly in their relation to the European Union and the US. Thus an alliance with Gülen would be only natural, since, as Kuru's statement pertaining to Hizmet indicates,

first the movement has been very successful in English instruction, which has been in high demand in many countries (...) The second resource of the movement is that it has created a synergy based on cooperation between educators and businesspeople. The sympathizers of the Gülen movement have been powerful enough to establish an interest-free bank and insurance company. Without the financial donations of businesses, the movement's schools could not afford to operate (2005, p. 262).

This demonstrates how new elites were opening to the world and how, by using globalization, they were able to break the monopoly on power of the old, secularist, Kemalist elite, which was quite statist in its essence. "Concurrently, 
new media, holdings related to old Sufi tarikatlar (brotherhoods), even Islamic banks and business associations like MÜSİAD or İ̧HAD (linked to Fetullah Gülen), (...) represented a bridge between modernity and the traditional Anatolian society" (Maigre, 2007, p. 36). Yet all of that started to fall apart in 2012, when Gulenists made a move on Erdoğan by inviting his chief of intelligence to testify in connection with PKK terrorist activities of the Kurdistan Workers Party (Partiya Karkerên Kurdistan, PKK) (Akyol, 2014). A power struggle arose and actions were taken by both sides, including Erdoğan closing down Gülen's prep-schools and a Gülen-instigated corruption probe involving some of Erdoğan's closest people.

During this time the phrase paralel devlet or "parallel state", so far used in political science (Briscoe, 2008; Pula, 2004; Sakallioğlu, 1997), came into public discourse. In its original usage, the term denotes organizations and institutions in the likeness of the legitimate state, without having legitimacy of its own, working for the sake of the existing country in accordance with the prevailing ideology (ParalelYap1, 2017). How hostile Erdoğan's discourse became can be noted by his use of the aforementioned phrase which, despite its value-neutral origins, became a vilified concept, presented as synonymous with Gülen and his ulterior motives, which entirely changed its original meaning.

In relation to 2013 Gezi Park protests, Lisel Hintz developed a categorization of three discursive mechanisms through which the AKP vilifies its opponents: naming, blaming, and framing (Hintz, 2016). While Gezi Park protestors were dubbed as çapulcular ("looters"), after 2015 Gülen's Hizmet organization became known under the acronym of FETÖ (Fethullahçı Terör Örgütü). This roughly translates to "Fetullah's terrorist organization", while the acronym FETÖ can serve as a rather derogatory nickname itself - a situation similar to the leader of the PKK, Abdullah Ocalan, being called Apo, a nickname popularized by the Turkish media (Özcan, 2006, p. 9). In other words, discursive creation of the enemy became the most efficient way to maintain electoral support, while the creator and perpetrator of the discourse could present himself as the "protector" against the enemy. The public opinion was turned against Gülen in a plethora of ways; by being presented as the main source of Turkish grievances, Gülen was successfully framed into already existing narratives, which in turn reinforced the culture of conspiratorial designs that had been already strong in Turkey. Pointing out that Gülen was backed by Israel and America is a famous example of such tactic (Yeni.Akit, 2016b).

However, Erdoğan's relations with Gülen were not the only thing that deteriorated during those years. In the research conducted by Birbil and Caliskan, 
one can see how Turkey's relations with the European Union, which had been much more positive before 2007-2008, worsened and reached an all-time low during the period of 2012-2013 (T24, 2014). This is of note, as during the days of the Erdoğan-Gülen alliance, Gülen could be seen as more conservative of the two, and therefore more nationalist, supporting religious values, and sceptical towards Europe and the accession process to the EU, as well as towards the resolution of the Kurdish issue (El-Kazaz, 2015, p. 5). After 2012, Erdoğan and the AKP could be seen adopting precisely such a policy. These findings can be interpreted in such a manner that before Ergenekon, Erdoğan indeed needed Europe against the Kemalists. He was playing the card of Turkish accession, constitutional reforms, changes and overall improvements of human rights -all the policies highly repressed during the heyday of secular Turkey. However, what essentially needs to be kept in mind in policy and discourse analysis is the question of cui bono, or who benefits (Frick \& Knight, 1994; Jovanović, 2013; Lundahl, 1989).

\section{Conspiracy discourses}

Immediately after the Ergenekon scandal, relations with Europe deteriorated; in other words, Turkey started reverting to its "olden ways". This was also noticeable in the 2011-2013 period, when Erdoğan hardened his discourse against the West during the strife with Gülen. One example of this is his use of the terms such as "Western conspiracies" as opposed to the notion of milli irade ("national will") and to the Muslims, which apparently in both cases he himself began to embody (Akyol, 2015). As early as in 1981, Goodnight and Poulakos wrote on conspiracy discourses in politics, explaining how "the 'paranoid style' no longer [could] be said to characterize only political extremists", and thus "a theory of conspiracy discourse must account for the usefulness of this appeal to mainstream speakers and audiences" (1981, p. 300); since that time, conspiracy discourses have become more and more frequently used on a global scale. Such "discourse constitutes a hint of people's hidden agendas and an expression of their individual psychodynamics. Thus, rhetoric becomes an 'exploratory system of events' which 'helps people transcend the everyday"' (Goodnight \& Poulakos, 1981, p. 301). As Gray wrote,

conspiracy theories are important symbols and dynamics in the politics of the Middle East: the salience of conspiracy theories in both popular and state discourses in the Middle East derives from a wide and complex set of sources. They are important both because of where they come from and for their impacts. 
They stem from political structures, competition between political actors, and the interaction of social groups and forces with each other and with the state. They also impact political dynamics, including the relationship between political elites, between elites and institutions (2008, p. 157).

This is why "successful [populist] parties pursue a 'post-modern' populist strategy that consciously appeals to widespread anxieties, prejudices, and resentments, and exploits them for political gain" (Betz, 2009, p. 194), as conspiracy plays directly into those anxieties, prejudices and resentments.

Yavuz and Ozcan mention how AKP's electoral success can be contributed to two factors: economic and political (2007, pp. 130-131). While it is true that economy was prosperous during the AKP's first two terms, these two authors see Erdoğan's charismatic personality as the most important political factor expressed through his body, language and overall lifestyle as a conservative people's man (Yavuz \& Ozcan, 2007, p. 130). This could explain why Erdoğan continued to enjoy public support despite adopting post-2012/2013 the same policies as Gülenists. The relative obscurity of Gülen and Hizmet community, coupled with its Sufi esoteric nature, which starkly contrasts Erdoğan's showman personality, is another point of interest. The trend became rather evident: whenever a power struggle occurred and human rights got side-lined, the Turkish leadership would present itself as the embodiment of the spirit of the people, representing their wishes and desires while external enemies were always out there waiting to hinder them. As Triandafyllidou wrote on national and populist discourses, "a common enemy (...) reminds them 'who we are' and emphasizes that 'we are different and unique'. In times of crisis, the significant other serves also as a scapegoat" (1998, p. 603). Thus Gülen was discursively cast into this role rather efficiently via government rhetoric and government controlled/influenced media, coupled with hyperproduction of conspiracy theories. The more serious the power struggle is, the harder the rhetoric will be. Akin Unver, a professor of international relations at Kadir Has University, stated tersely: "Whenever something shocking and horrific happens in Turkey, the reflex is conspiracy" (Arango \& Yeginsu, 2016). When the AKP won the 2011 elections and talks of tighter centralization of powers in the president's hands began to be heard, Erdoğan's rhetoric during some of his public rallies and outreaches was so radical that Cerrahoğlu (2015) envisioned him as Louis XIV saying "L'etat c'est moi". Thus the media and democracy were under constant pressure (Akser \& BaybarsHawks, 2012; Kaya \& Çakmur, 2010) from what was becoming a nearly fully fledged authoritarian mode of governance, aiming solely at preservation and expansion of power. The leader of the Republican People's Party (CHP), Kemal 
Kilicdaroglu, called out the AKP on the police and judicial operations conducted against certain media outlets in 2014, even going as far as to proclaim that the government was staging a coup against democracy (Haberler, 2014).

\section{After the 2016 coup: open authoritarianism}

The culmination of this five-year struggle between Erdoğan and the Gülenists was the 2016 attempt of a coup d'etat. In the summer of 2016, rumors were going around that certain Gülenists would be discharged from the military - the same people which filled the army ranks after the purges following the Ergenekon case (Rodrik, 2016). Whether this was true or not, a coup was attempted - most probably by various factions within the military forces, out of which most notable were the Gülenists - and was quickly suppressed. What exactly happened prior to and during the coup is still unknown. Following this attempt, a large scale violation of human rights, prosecutions, arrests, removals from workplace, and media oppression occurred state-wide, including 162 journalists arrested, 138,610 people sacked, 94,982 people detained, 4,272 judges and prosecutors dismissed, 149 media outlets shut down, 2,099 schools and dormitories shut down, and numerous other civil and human rights violations continuing for several years (Turkeypurge.com, 2017). This creates an impression that the government was waiting for a pretext to introduce such wide-sweeping measures. Though this cannot be corroborated, the cui bono question does have an answer: it can be found in Erdoğan's rhetoric as he himself stated that the coup was a "gift from God" (Champion, 2016). The purge went to such extremes that Kilicdaroğlu proclaimed that "the Turkish government is going too far", lobbying for the release of the arrested writer Asli Erdoğan (Hurriyet, 2016). In the aftermath of the coup, even the slightest criticism of the government or official state policies or any sort of contact with Gülenists (such as staying in one of their student dormitories) could be incriminatory under Erdoğan's state of emergency (ohal durumu). As Yesil wrote, "the AKP (...) exacerbated the existing repressive environment by abusing the legal framework to criminalize Kurdish journalists, by instrumentalising a major political investigation - the Ergenekon to prosecute dissenting journalists, and by exploiting its economic relationships with media conglomerates to engender self-censorship in the press" (2014, p. 1), drawing a grim picture of the censorship and media repression in the post-coup Turkey. It has long been theorised that it is the duty of the press to keep the checks and balances within the state as a vital part of the democratic process (Curran, 2011; Dahlgren, 2009; McNair, 2012); the state of the media under Erdoğan has, however, been moving 
increasingly in the opposite direction. What is problematic is that despite alleged criminal/terrorist dealings, Gülenists ran a large number of institutions and organizations which were mostly of educational/charitable character; thus repressions particularly touched certain demographics such as students, foreigners, or the destitute. More often than not that the post-coup Turkish government seems to follow the "guilty until proven innocent" adage.

The authors believe it would be pertinent here to contrast the types of campaigns which the AKP led during the early 2000s and now. Whilst in league with Gülen against Kemalists, the discourse which dominated the AKP's public campaigns was based on "victimization" and the framing of ordinary, conservative Turks as mazlumlar or the "wronged ones against the privileged secularist elites known as Beyaz Türkler or White Turks" (Yavuz \& Ozcan, 2007). Ever since the AKP entered into open struggle with Gülenists in the context of secular establishment's disenfranchisement, the AKP's rhetoric changed its tone and placed itself along Black Turks in the position of power, threatening the country with the Kurdish issue, terrorism, and poor economic conditions that might arise if coalitional governments came to power. While during its first terms the AKP was employing what Sornig dubs a "seductive strategy" in its discourse of political persuasion (1989, pp. 97-98), in the later period, especially during the 2015 battle for votes in the general election, it switched to the coercive side of the spectrum, where the recipient, i.e. the people, were asked to adjust their behaviour in line with the requirements of the persuaders.

Returning to the previously mentioned statement of Akin Unver, it is evident to what extent the state-influenced media control and shape the public discourse within Turkey. According to Freedom House, since 2015 the media in Turkey have been coming under increasingly tight control of the state, and a great number of journalists have been arrested (162 up to the point of writing this article), while many previously influential media houses have been either closed down (149), or had a change in leadership (FreedomHouse, 2016). By using the media in this way, Erdoğan is directly creating a polarizing discourse which demonizes everyone who has even the slightest inkling of dissatisfaction with authorities as them, and only them, embody the "will of the people", with Erdoğan discursively positioning himself at the apex of this structure, securing votes and popularity. This type of opinion spun through the media is an ideal tool for Erdoğan's type of pseudo-democracy based on populist voting and referendums as the ultimate methods of governmental legitimation, resembling somewhat Viktor Orban's oxymoronic discursive construction, the "illiberal democracy" (Bugaric, 2008, p. 198). Western countries which criticize Erdoğan over issues such as the unfair 
judicial process and an overall lack of liberal democracy were among the first targets for his regime; how they are presented is entirely skewed in the public discourse. A good example of this is a Twitter poll created by a well-known government-backed newspaper, the Daily Sabah, asking the Turkish public to state their opinion as to which US institution backed Gülen in organizing the coup attempt; the choices offered were the CIA, the FBI, the Department of State, and the White House (Sabah, 2016). The questionnaire offered no options that the coup was not orchestrated by the US, thus reinforcing the negative portrayal of that state.

This entire discursive structure created a myriad of polarizing factors within the society since Erdoğan's universalist rhetoric attitude leaves no room for inclusivity, and thus political and public discourse became dominated by what in 2017 came to be known as "alternative facts". The strength of such discourse becomes immediately enhanced, considering that Erdoğan does not avoid involving religion as a factor, which compounds the normativity of his presentation. Shades of metaphysical involvement, predestination and ontological chosen-ness of some over others are very discernible. Immediately after the failed coup attempt, the government started using the phrase taken from an Islamist/conservative poet, Sezai Karakoç, ascribing their salvation to the involvement of higher powers: "Ne yapsalar boş göklerden gelen bir karar vardır" (Yeni.Akit, 2016a), roughly translating to "No matter what they do, there is a decision coming from the heavens". Erdoğan was known to incorporate this phrase along with the rest of the poem in his speeches; Istanbul was plastered with billboards which carried the aforementioned verse. Furthermore, after the night of 15 June, the people who got killed in the skirmishes with the armed forces were quickly dubbed as "martyrs" by the official state sources, and their families were extended various benefits for their support of the constitutional order and the removal of the threats to national unity, togetherness, and various other values, which came "under attack". A so-called "martyrdom discourse" was established (Damir-Geilsdorf, 2004; Moss, 2012) via lexical choice. What is important to note is the discourse the official state apparatus uses, dubbing those who apparently organized the "vile" coup attempt as traitors, while the public and the president's wisdom (which is the embodiment of the former) ultimately prevailed over the "abominable" enemy, as propounded officially by the Presidency (Başbakanlık, 2016). Moreover, the government renamed some of the key infrastructural elements of Istanbul, such as bridges or bus/metro/metrobus stations, with the names of coup attempt victims or terms which invoke related imagery (Gazetesi, 2016). This can be seen either as a genuine appreciation of 
the those fallen on the night of July 15 coup attempt, or as a clear attempt to accentuate government's own legitimacy in the eyes of the people and side-line all of its social and political adversaries who, apparently, according to the official state discourse, do not embody the "will of the people". This type of exclusion from the political space - through very bold public discourse - is of horizontal form, where a dichotomous relationship exists and the society is divided into "us versus them", side-lining a vertical type of exclusion where obvious and empirically measurable wealth gaps can be detected (Taket et al., 2009, p. 10); Turkey does have an acute problem with the wealth gap, according to the 2016 Global Wealth Report (Kersley \& Koutsoukis, 2016).

Moreover, the ruling Justice and Development Party used the coup attempt as the final straw, a determinant which tipped the scales towards the implementation of new amendments to the constitution in favor of a presidential system. This can be viewed as a culmination of a process towards which Erdoğan's party was striving for a long time. By the vote conducted on 21 January 2017, the Turkish parliament approved the bill which would give a significant authority increase to the president of the Republic, and the referendum which was announced for the spring of 2017 was the only instance that could have prevented its full $d e$ jure implementation (Hacaoglu \& Kozok, 2017). As far as the referendum itself is concerned, the Erdoğan-backed and AKP-led campaign of evet (yes) to constitutional revision and a presidential system was fully promoted from its official starting date on 25 February (A.Haber, 2017). According to the article 48 of the Turkish constitution, the president of the Republic, if elected by the Grand National Assembly from within the party, necessarily has to cut all his ties to the said party and practice full impartiality. Yet with Erdoğan siding with and promoting the program of his "former" party, the main constitutional tenets are therefore brought into jeopardy. It is akin to using non-constitutional means to amend the constitution itself. A good example of this is Erdoğan's speech from Mersin where he called upon the audience to answer with evet and hayir (options that would be included on the constitutional referendum ballots) to the overtly leading and manipulative questions (Sözcü, 2017). Weeks later a route consisting of five cities was created, which would serve as his stops in the promotion of the evet kampanyasi (Birgün, 2017).

After the coup, further populist measures were introduced, resulting in Erdoğan's popularity increase. He started to use referendums as means to accomplish his goals, skewing and manipulating the public opinion. It is important to note how Erdoğan's use of referendums is extremely reductionist in nature, thus simplifying an already complex situation to a simple evet or hayir. 
It was already noted by Margaret Thatcher, who referenced back to Lord Attlee, how referendums can be dangerous and undemocratic tools working in favour of those in power, as "perhaps the late Lord Attlee was right when he said that the referendum was a device of dictators and demagogues" (Stephens, 2007). However, Erdoğan did not stop at a single plebiscite. Besides giving implicit and explicit support for the referendum on constitutional change, he also announced a referendum concerning the return of the death penalty, which was in line with his conservative rhetoric. What is important to note is that in 2004, during Erdoğan's time as a prime minister, a bill was signed which abolished the capital punishment (Özgönül, 2017). That was back in a day when Turkey worked on its path towards EU accession. In what can be considered a true populist fashion, Erdoğan often delegated his own wishes to the "will of the people" and "national interest". The death penalty debate went no different:

My citizens rightly speak of execution. This decision is held by the parliament. If such decision comes, I will approve it. Some Europeans ask why we talk of capital punishment. I say to them: "Sovereignty without any reservations belongs to the people". Our country is run by democracy. Above the people's decision, there is no other decision. The great majority of the world today has capital punishment. Recently, a man who was captured in America 19 years ago, was executed. They lecture us, but they should rather keep it to themselves (Haber7, 2016).

What he stated here was how all "will" lies with "the people", and how there is no decision above it, and should the parliament pass it, he would do so as well. The "will of the people", as scholarly work on populism and political discourse concludes, is a recurring theme, as

by appealing implicitly to the people, a populist communication style stresses the sovereignty of the people and the popular will. Political actors speak about the people all the time. They frequently use words such as (the) people, (the) public, (the) citizen(s), (the) voter(s), (the) taxpayer(s), (the) resident(s), (the) consumer(s), (the) population (...). By referring to the people a political actor claims that he or she cares about the people's concerns, that he or she primarily wants to defend the interests of the people, that he or she is not alienated from the public but knows what the people really want. The implicit populist's motto is: "I listen to you because I talk about you" (Jagers \& Walgrave, 2007, pp. 3-4).

Furthermore, "appealing to the people forms the essential core of populism. Without reference to the people, populism is unthinkable. In all available definitions appealing to the people is a minimal and necessary condition" (Jagers \& Walgrave, 2007, p. 4). Erdoğan's politics and rhetoric are favourable only to particular segments of population, that is, to people of conservative, religious 
and mostly rural backgrounds. To put it in the words of Serif Mardin, "until recently, the confrontation between centre and periphery was the most important social cleavage underlying Turkish politics and one that seemed to have survived more than a century of modernization" (1973, p. 170).

\section{Conclusions}

With the AKP coming to power, the periphery penetrated the centre, which has not happened often in the modern Turkish history, due to the vehement disapproval of the Kemalist secular establishment. An examination of official statistics makes it clear that Turkey is still behind the countries of the OECD in terms of primary, secondary and tertiary education, albeit with significant improvements have been made over the years (OECD, 2013). If one observes regional differences within Turkey, the results are even more striking. Around 39\% of the women are illiterate in the Southeast, and around $21 \%$ in the Black Sea region; around $9 \%$ of the men and $30.8 \%$ of the women are illiterate in the rural areas. What this tells us is that the periphery in Turkey still suffers from lack of education, and as such, it is subject to majoritarian manipulations in the political arena. As Filiztekin and Bakis state, in order for the periphery (which is, according to Mardin, mostly composed out of peasants, farmers and artisans) to shield itself against radical modernization attempts by the centre, it often relies on religion as well as on ethnic or local ties, and it would appear that the periphery continues to elect the AKP as its representative. In conclusion, they mention that location indeed shapes electoral outcomes, which the AKP found favourable (Filiztekin \& Bakis, 2014). This strongly ties in with the research which Dahl expounded in his seminal text A Preface to Democratic Theory, where he measured the correlation between a person's socioeconomic standing with their political preference: the lower it is, the more likely it will be that their political choices will be authoritarian; additionally, they are less likely to be active politically (2006, p. 89). What this tells us is that the worse the person's socioeconomic standing is, the more likely they are to become attracted by dogmatic machinations of politicians who know how to manifest a strong, authoritarian sentiment, as well as by appropriate discourses. Erdoğan and the AKP seem to be aware of this, counting on the support of exactly that "peripheral" sector of the electorate. Out of the periphery, only the chosen few reap the benefits (as the 2014 Global Wealth Report shows), while the rest are being "whipped into submission" by violent discourse, international and domestic rows, scandals and political threats. To this end, before any sort of majoritarian-based political event, one of these aforementioned 
exclusionary methods and discourses are bound to be used. A good example is the recent political scandal involving the Netherlands, which escalated with immense speed, whilst Erdoğan was using decidedly undiplomatic language, even blaming the Netherlands for the 1995 Srebrenica massacre (Hurriyet, 2014). An anti-consensual majoritarian approach to democracy is being taken in Turkey, one that can be classified as "populist-majoritarian" in the typology of Marxer and Pállinger (2009, pp. 35-36). This mode of governance is strongly supported by a set of discursive practices aimed at creating the "enemy" to be fought by Erdoğan himself, while he enjoys increasing popularity.

\section{REFERENCES}

A.Haber. (2017, Feb 25). AK Parti'nın 'Evet' kampanyası resmen start ald1. A.Haber). Retrieved from http://www.ahaber.com.tr/gundem/2017/02/25/ak-partinin-evetkampanyasi-resmen-start-aldi

Akser, M., \& Baybars-Hawks, B. (2012). Media and democracy in Turkey: Toward a model of neoliberal media autocracy. Middle East Journal of Culture and Communication, 5(3), 302-321.

Akyol, M. (2014, Jan 3). What you should know about Turkey's AKP-Gulen conflict. AI-Monitor. Retrieved from http://www.al-monitor.com/pulse/originals/2014/01/ akp-gulen-conflict-guide.html

Akyol, M. (2015, Feb 2). What turned Erdogan against the West. AI-Monitor. Retrieved from http://www.al-monitor.com/pulse/originals/2015/02/turkey-erdogan-anti-west. html

Arango, T. (2014, Feb 26). Turkish Leader Disowns Trials That Helped Him Tame Military. The New York Times. Retrieved from https://www.nytimes.com/2014/02/27/ world/europe/turkish-leader-disowns-trials-that-helped-him-tame-military. html?_r=0

Arango, T., \& Yeginsu, C. (2016, Aug 2). Turks Can Agree on One Thing: U.S. Was Behind Failed Coup. The New York Times. Retrieved from https://www.nytimes. com/2016/08/03/world/europe/turkey-coup-erdogan-fethullah-gulen-unitedstates.html?_r=0

Arin, K. Y. (2017). Turkey's New Foreign Policy: The Quest for Regional Hegemony in the Middle East? The Copernicus Journal of Political Studies, 2, 45-57.

Aytaç, S. E., \& Çarkoğlu, A. (2019). Ethnicity and religiosity-based prejudice in Turkey: Evidence from a survey experiment. International Political Science Review, 40(1), $58-72$.

Başbakanlık, T. C. (2016). 15 Temmuz Şehitleri Dayanışma Kampanyası. Ankara. Retrieved from https://www.basbakanlik.gov.tr/Forms/_Article/pg_Article.aspx?Id= 48dfb4bd-9199-47a1-afd5-cf4bc7b5b386. 
BBC. (2013, Dec 18). Profile: Fetullah Gulen's Hizmet movement. BBC. Retrieved from http://www.bbc.com/news/world-13503361

Betz, H.-G. (2009). Xenophobia, identity politics and exclusionary populism in Western Europe. Socialist Register, 39(39), 193-210.

Birgün. (2017, Feb 15). Erdoğan'nn 'evet' kampanyasında ilk durak Maraş. Birgün Gazetesi. Retrieved from http://www.birgun.net/haber-detay/erdogan-in-evet-kampanyasinda-ilk-durak-maras-146958.html

Briscoe, I. (2008). The Proliferation of the Parallel State. Madrid: Fundación para las Relaciones Internacionales y el Diálogo Exterior, Working Paper, 71.

Bugaric, B. (2008). Populism, liberal democracy, and the rule of law in Central and Eastern Europe. Communist and Post-Communist Studies, 41(2), 191-203.

Cagaptay, S. (2019). Making Turkey Great Again. Fletcher F. World Aff. 43, 169.

Carpentier, N. (2011). The Ideological Model of War: Discursive Mediations of the Self and the Enemy. Creating destruction: constructing images of violence and genocide 1.

Cerrahoğlu, N. (2015, Aug 18). Erdoğan: 'Devlet benim!'. Cumhuriyet. Retrieved from http://www.cumhuriyet.com.tr/koseyazisi/347529/Erdogan___Devlet_benim__html

Champion, M. (2016, Jul 17). Coup Was 'Gift From God' for Erdogan Planning a New Turkey. Bloomberg. Retrieved from https://www.bloomberg.com/news/articles/2016-07-17/coup-was-a-gift-from-god-says-erdogan-who-plans-a-new-turkey Chaney, P. (2013). Electoral discourse analysis of state foreign policy development: exploring the party politicization of the Commonwealth in UK Westminster elections 1945-2010. Contemporary Politics, 19(2), 203-220.

Christensen, M. (2010). Notes on the public sphere on a national and post-national axis Journalism and freedom of expression in Turkey. Global Media and Communication, 6(2), 177-197.

Curran, J. (2011). Media and democracy: Taylor \& Francis.

D’Amours, J. (2017, Jul 21). Analysis: Dissecting Turkey's Gulen-Erdogan Relationship. Middle East Ey. Retrieved from http://www.middleeasteye.net/news/analysis-dissecting-turkeys-gulen-erdogan-relationship-528239159.

Dahl, R. A. (2006). Preface to Democratic Theory (Expanded Edition). Retrieved from http://public.eblib.com/choice/publicfullrecord.aspx? $\mathrm{p}=3563038$

Dahlgren, P. (2009). Media and political engagement: Cambridge: Cambridge University Press.

Daily Sabah. (2016, Jun 30). Which institution of the US provided largest support to Gülenist terror group? Daily Sabah. Retrieved from https://twitter.com/DailySabah/ status/756575396301312000Damir-Geilsdorf, S. (2004). Martyrdom \& Resistance in the Middle East. ISIM Newsletter, 14, 2.

Đidić, A. (2017). Realism in Turkish Foreign Policy Towards Syrian Refugees. Savremena politika i upravljanje, 3(1), 6-28.

Dorsey, J. M. (2016). Fethullah Gulen: Moderniser or Wolf in Sheep's Clothing? RSIS Commentary. Singapore: S. Rajatnam School of International Studies. 
Economist, the. (2013, May 18). Turkey's political imams: The Gulenists fight back. The Economist. Retrieved from http://www.economist.com/news/europe/21578113muslim-cleric-america-wields-surprising-political-power-turkey-gulenists-fight-back

El-Kazaz, S. (2015). The AKP and the Gülen: The End of a Historic Alliance. Crown Center for Middle East Studies, 94.

Filiztekin, A., \& Bakis, O. (2014). The Geography of AKP votes. Paper presented at the 34th annual meeting of The Middle East Economic Association, Philadelphia.

FreedomHouse. (2016). Turkey. Freedom of the press 2016: Freedom House.

Frick, F. S., \& Knight, D. (1994). Cui Bono?-History in the Service of Political Nationalism: The Deuteronomistic History as Political Propaganda. Semeia, 66, 79-92.

Gazetesi, Y. (2016, Jul 26). Boğaziçi Köprüsü’nün adı değişti! Yeniçağ Gazetesi. Retrieved from http://www.yenicaggazetesi.com.tr/bogazici-koprusunun-adi-degisti-142740h. htm

Goodnight, G. T., \& Poulakos, J. (1981). Conspiracy rhetoric: From pragmatism to fantasy in public discourse. Western Journal of Speech Communication 45(4), 299-316.

Gray, M. (2008). Explaining conspiracy theories in modern Arab Middle Eastern political discourse: some problems and limitations of the literature. Critique: Critical Middle Eastern Studies, 17(2), 155-174.

Haber7. (2016, Oct 27). Erdoğan 'idam cezası' için noktayı koydu! Haber7. Retrieved from http://www.haber7.com/ic-politika/haber/2191764-erdogan-idam-cezasi-icinnoktayi-koydu

Haberler. (2014, Dec 14). Kılıçdaroğlu: Demokrasiye Darbe Yapılıyor. Haberler. Retrieved from http://www.haberler.com/kilicdaroglu-demokrasiye-darbe-yapiliyor6773994-haberi

Hacaoglu, S., \& Kozok, F. (2017, Jan 21). Turkey Parliament Triggers Referendum on Presidential System. Bloomberg. Retrieved from https://www.bloomberg.com/news/ articles/2017-01-21/turkey-parliament-triggers-referendum-on-presidential-systemiy6kd8n6

Hintz, L. (2016). Adding Insult to Injury: Vilification as Counter-Mobilization in Turkey's Gezi Protests. Paper presented as part of the project From Mobilization to CounterRevolution: The Arab Spring in Comparative Perspective.

Howarth, D., \& Torfing, J. (2004). Discourse theory in European politics: identity, policy and governance. London: Palgrave Macmillan UK. DOI: https://doi.org/10. $1057 / 9780230523364$

Hurriyet. (2014, Mar 14). Cumhurbaşkanı Erdoğan'dan Hollanda'ya çok sert 'Srebrenitsa' çıkışı! Hollanda'dan yanıt geldi... Hurriyet. Retrieved from http://www.hurriyet. com.tr/erdogandan-srebrenitsa-cikisi-hollandadan-yanit-geldi-40394978

Hurriyet. (2016, Aug 28). Turkish gov't going too far in post-coup attempt state of emergency measures: CHP head Kılıçdaroğlu. Hurriyet. Retrieved from http://www. hurriyetdailynews.com/turkish-govt-going-too-far-in-post-coup-attempt-state-ofemergency-measures-chp-head-kilicdaroglu-.aspx?pageID $=238 \& n I D=103307 \& \mathrm{Ne}$ wsCatID $=338$ 
Jäger, S. (2001). Discourse and knowledge: Theoretical and methodological aspects of a critical discourse and dispositive analysis. In R. Wodak \& M. Meyer (Eds.), Methods of critical discourse analysis (Vol. 2, pp. 32-63). DOI: http://dx.doi. org/10.4135/9780857028020

Jagers, J., \& Walgrave, S. (2007). Populism as political communication style: An empirical study of political parties' discourse in Belgium. European Journal of Political Research, 46(3), 319-345.

Jenkins, G. (2012). A house divided against itself: the deteriorating state of media freedom in Turkey. Central Asia-Caucasus Institute Silk Road Studies Program.

Jovanović, S. M. (2013). Dobro upravljanje - cui bono? Elite, politike, nasilje i raspad Jugoslavije. Savremena politika i upravljanje, 1(1), 8--19.

Jovanović, S. M., \& Đidić, A. (2018). How Carl Schmitt and the Copenhagen School Are still Relevant for Understanding Turkey: The Presidential System Explained Through a Security Lens. Political Sciences / Politicke Vedy, 21(2), 8-25.

Kaya, R., \& Çakmur, B. (2010). Politics and the mass media in Turkey. Turkish Studies, 11(4), 521-537.

Kersley, R., \& Koutsoukis, A. (2016). The Global Wealth Report 2016. Credit-Suisse Research Institute.

Kösebalaban, H. (2011). Turkish foreign policy: Islam, nationalism, and globalization. London: Palgrave Macmillan UK.

Krastev, I. (2007). The populist moment. Eurozine. Retrieved from http://www.eurozine. com/articles/2007-09-18-krastev-en.html

Kuru, A. T. (2005). Globalization and diversification of Islamic movements: three Turkish cases. Political Science Quarterly, 120(2), 253-274.

Larsen, H. (2005). Foreign policy and discourse analysis: France, Britain and Europe (Vol. 10). London: Routledge. DOI: https://doi.org/10.4324/9780203992708

Link, J. (1983). Was ist und was bringt Diskurstaktik. KultuRRevolution, 2, 60-66.

Lundahl, M. (1989). Apartheid: cui bono? World development, 17(6), 825-837.

Maigre, M.-E. (2007). The influence of the Gülen Movement in the emergence of a Turkish cultural third way. Muslim World in Transition. London: Leeds Metropolitan University Press.

Mann, J., \& Rodgers, W. (2002, Nov 4). Europe hails AKP victory in Turkey. BBC. Retrieved from http://edition.cnn.com/2002/WORLD/europe/11/04/turkey.elections/ Mardin, Ş. (1973). Center-Periphery Relations: A Key to Turkish Politics? Daedalus, 102. Marxer, W., \& Pállinger, Z. T. (2009). Stabilizing or destabilizing? Direct-democratic instruments in different political systems. Referendums and Representative Democracy. Responsiveness, Accountability and Deliberation. ECPR Studies in European Political Science, 62, 34-55.

McNair, B. (2012). Journalism and democracy: An evaluation of the political public sphere. London: Routledge.

Moss, C. R. (2012). The discourse of voluntary martyrdom: Ancient and modern. Church History, 81(03), 531-551. 
Mouffe, C. (1993). The Return of the Political. London: Verso.

Mudde, C. (2004). The populist zeitgeist. Government and opposition, 39(4), 542-563.

Mudde, C., \& Kaltwasser, C. R. (2012). Populism in Europe and the Americas: Threat or corrective for democracy? Cambridge: Cambridge University Press.

Müller, J.-W. (2016). What is Populism? Philadelphia: University of Pennsylvania Press.

OECD. (2013). Education at a Glance 2013: OECD Indicators.

Oktay, S. (2016). The Role of the Judiciary and the Rule of Law in Democratization: The Case of Turkey and the Chances of Democratic Consolidation (M.A. thesis). Denver: University of Denver. Retrieved from http://digitalcommons.du.edu/cgi/ viewcontent.cgi?article $=2092 \&$ context $=$ etd

Özcan, K. A. (2006). Turkey's Kurds: A theoretical analysis of the PKK and Abdullah Öcalan. New York: Routledge.

Özdamar, Ö., \& Ceydilek, E. (2020). European populist radical right leaders' foreign policy beliefs: An operational code analysis. European journal of international relations, 26(1), 137-162.

Özgönül, E. (2017, Feb 26). 2004 yılında kaldırdıkları idamı referanduma malzeme yapiyorlar. Sözcü. Retrieved from http://www.sozcu.com.tr/2017/gundem/2004yilinda-kaldirdiklari-idami-referanduma-malzeme-yapiyorlar-1700794

Özsoy, A. (2009, Sep 7). Güçsüz Ordu Güçsüz Türkiye. Retrieved from http://www. turksolu.com.tr/sehit/secmeordu5.htm

ParalelYapı. (2017). Paralel devlet nedir? Paralel Yapı. Retrieved from http://paralelyapi. nedir.net.tr

Pula, B. (2004). The emergence of the Kosovo "parallel state", 1988-1992 1. Nationalities Papers, 32(4), 797-826.

Rodrik, D. (2016). Is Fethullah Gülen behind Turkey's coup? In D. Rodrik (Ed.), Dani Rodrik's weblog (Vol. 2017).

Rydgren, J. (2005). Is extreme right-wing populism contagious? Explaining the emergence of a new party family. European Journal of Political Research, 44(3), 413-437. Sakallioğlu, Ü. C. (1997). The anatomy of the Turkish military's political autonomy. Comparative Politics, 29(2), 151-166.

Sharon-Krespin, R. (2009). Fetullah Gullen's Grand Ambition: Turkey's Islamist Danger. The Middle East Quarterly, 16, 55-56.

Sornig, K. (1989). Some remarks on linguistic strategies of persuasion. Language, power and ideology: Studies in political discourse, 7, 95.

Sözcü. (201, Feb 3). Erdoğan bir türlü istediği cevabı alamadı! Sözcü. Retrieved from http://www.sozcu.com.tr/2017/gundem/erdogan-bir-turlu-istedigi-cevabi-alamadi-1659349

Stephens, P. (2007, Sep 11). Thatcher was right about referendums. Financial Times. Retrieved from http://www.ft.com/cms/s/0/935c343c-6007-11dc-b0fe0000779fd2ac. html?ft_site=falcon\&desktop=true\#axzz4aAlZYnyh

T24. (2014, Nov 5). Batı́nın gözünde yeni Erdoğan: İslamcı ve Otoriter. T24. 
Taggart, P. (2002). Populism and the pathology of representative politics. In Y. Meny, \& Y. Surel (Eds.), Democracies and the populist challenge (pp. 62-80). Palgrave Macmillan UK. DOI: 10.1057/9781403920072.

Taguieff, P.-A. (1995). Political science confronts populism: from a conceptual mirage to a real problem. Telos, 103, 9-43.

Taket, A., Crisp, B. R., Nevill, A., Lamaro, G., Graham, M., \& Barter-Godfrey, S. (2009). Theorising social exclusion. London: Routledge.

Triandafyllidou, A. (1998). National identity and the 'other'. Ethnic and Racial Studies, 21(4), 593-612.

Turkeypurge.com. (2017).

Van Leeuwen, T. (1993). Genre and field in critical discourse analysis: A synopsis. Discourse \& Society, 4(2), 193-223.

Wodak, R. (2001). What CDA is about - a summary of its history, important concepts and its developments. In R. Wodak \& M. Meyer (Eds.), Methods of critical discourse analysis (pp. 1-12). London, Thousand Oaks, New Delhi: SAGE Publications.

Yavuz, H. M., \& Ozcan, N. A. (2007). Crisis in Turkey: The Conflict of Political Languages. Middle East Policy, 14.

Yavuz, M. H., \& Öztürk, A. E. (2019). Turkish secularism and Islam under the reign of Erdoğan: Southeast European and Black Sea Studies, 19(1), 1-9. DOI: https://doi.org /10.1080/14683857.2019.1580828

Yeni.Akit. (2016a, Jun 30). 'Ne yapsalar boş göklerden gelen bir karar vardır!'. Yeni Akit. Retrieved from http://www.yeniakit.com.tr/haber/ne-yapsalar-bos-goklerdengelen-bir-karar-vardir-190032.html

Yeni.Akit. (2016b, Aug 23). Yahudi cemaati: Gülen sen bizim Mesih'imizsin. Yeni Akit. Retrieved from http://www.yeniakit.com.tr/haber/yahudi-cemaati-gulen-sen-bizimmesihimizsin-205017.html

Yesil, B. (2014). Press Censorship in Turkey: Networks of State Power, Commercial Pressures, and Self-Censorship. Communication, Culture \& Critique, 7(2), 154-173.

Yılmaz, G. (2016). Europeanisation or de-Europeanisation? Media freedom in Turkey (1999-2015). South European Society and Politics, 21(1), 147-161.

Yilmaz, I., Caman, M. E., \& Bashirov, G. (2020). How an Islamist party managed to legitimate its authoritarianization in the eyes of the secularist opposition: the case of Turkey. Democratization, 27(2), 265-282.

Zubaida, S. (2017, May 30). Turkey as a model of democracy and Islam. Open Democracy. Retrieved from https://www.opendemocracy.net/en/north-africa-west-asia/turkeyas-model-of-democracy-and-islam/ 